\title{
Assessment of Farm Labour Constraints in Esan West Local Government Area of Edo State, Nigeria
}

\author{
Idiake-Ochei O* \\ Department of Agricultural Economics and Extension, Ambrose Alli University, Ekpoma, Edo State, Nigeria \\ *Corresponding Author \\ Idiake-Ochei $\mathrm{O}$ \\ Article History \\ Received: 12.07.2019 \\ Accepted: 22.07.2019 \\ Published: 30.07 .2019
}

\begin{abstract}
The study assessed the farm labour constraints in Esan west local government area of Edo state, Nigeria. Specifically, it identified the types of farm labour used for some farming activities and also ascertained the constraints faced by farmers in using farm labour. Survey method was used to sample 108 respondents from four (4) purposively selected villages in the study area. Data were analyzed using descriptive and inferential statistical tools. The result revealed that Most of the respondents used family and hired labour in carrying out most of their farming activities. The major constraints of the farmers in the study area were high cost of labour $($ mean $=2.84)$ and lack of finance $($ mean $=2.83$ ). The result also revealed that there was a significant difference among the constraints faced by the respondents with high cost of labour (mean rank $=3.456$ ) being the most significant serious constraint. It was recommended that the farmers organise themselves into associations to assist each other rotationally in terms of providing labour.
\end{abstract}

Keywords: labour constraints, farmers, associations

\section{INTRODUCTION}

Labour plays important economic and social roles in any economy. It is one of the key factors of production as well as a source of livelihood to billions of people worldwide [1]. Nigeria's agricultural production is highly labour intensive. Over $90 \%$ of nonmechanized production systems depend on human labour, and for mechanized production systems, between 50 and $60 \%$ of the tasks depend on human labour $[2,3]$.

Labour is a major constraint in food crop production [4]. The availability of labour has been found to have impact on planting precision, better weed control, timely harvesting and crop processing [5]. According to Tanko, Onyenweaku and Nwosu [6], Nigeria's food deficient situation has been worsened by declining farm productivity owing to inefficient production techniques, poor resource base and "insufficient farm labour" supply among others, Francis [7] reported that labor supply could be a barrier to adoption of a more sustainable agriculture as a result of ageing farm operators, deteriorating health through diseases and seasonal nature of farming. labour has been found to constitute a large proportion of cost in the food crop production process in Nigeria and its productivity has become increasingly low because farm households largely comprised fairly old people and very young children coupled with the use of crude implements which impede their ability to raise yield of food crops and income with subsequent reduction in poverty level.

In Nigeria, farm labour is a major source of employment opportunity for the rural labour force and technological change is one of the major forces leading to change in employment, output and functional income distribution. In recent years, the introduction and distribution of technologies such as farm power and machinery, improved planting materials and production of chemical fertilizers have brought about substantial increase in agricultural productivity in Nigeria [2]. According to Adeoti [8], although the growth rate in the agricultural sector in Nigeria increased from an average of about $7 \%$ in the mid-2000, the food security in Nigeria has continued to decline.

Many factors have been identified as reasons why agriculture is not doing so well; some of these reasons are poor infrastructure, dormant research facilities, education and modernization, unserviceable machinery, food processing issues and government policies [9]. Farm labor is also identified to be one of the problems confronting agriculture in the country. Farm labour also

Copyright @ 2019: This is an open-access article distributed under the terms of the Creative Commons Attribution license which permits unrestricted use, distribution, and reproduction in any medium for non commercial use (NonCommercial, or CC-BY-NC) provided the original author and source are credited. 
called farmworker, which is a hired agricultural worker on a farm that works for the farmers [10] constitutes a very important factor of production.

According to Oluyole et al., [5], the unavailability of farm labour has also been found to have negative impact on planting precision, better weed control, timely completion of harvesting and crop processing. Labour therefore is a major constraint in peasant production especially during early planting, weeding and harvesting [4].

Agricultural production and access to labour vary substantially around the world. Agriculture is marked by a high degree of risk; thus, considerations of risk are a hallmark of agricultural decision making [11]. There are two broad categories of risk in agriculture: Production risk and marketing risk (Harvests and sales are uncertain). They are shaped by variables beyond producers' control, including pest and weather risks and availability of labour. This sort of uncertainty does not arise in manufacturing, where production processes are governed primarily by engineering relationships. Whether farmers have access to hired workers and a market for the harvested crop directly impacts how farmers respond to seasonality, uncertainty, and risk in agricultural production

Labour supply risks are paramount at harvest time. An important potential component of risk is the lack of available labor at the times and places needed to harvest crops. Production risk can result from an insufficient labor supply if fruit spoils on the trees before it can be harvested or if labor shortages prevent farmers from complying with their contractual obligations higher up on the supply chain.

The sequential nature of crop production and risk mean that farm labor cannot be treated like other production inputs. Agricultural labor demands are aggregated from the demands of many farms scattered across a large geographic space. The number of workers needed on a farm fluctuates seasonally, and there is a high level of uncertainty about the farm labor demand from the time of planting a crop to its harvest. The supply of farm workers is also dynamic. Many have said that the reason why farmers are not doing so well is as a result of the unavailability of farm labor or the limited access to farm labor, hence, the need to investigate farm labor issues in Esan west LGA of Edo state. To this end, the study sought to provide answers to the following questions:

\section{Research Questions}

1. What types of farm labour are used by the farmers for some farming activities in the study area?

2. What are the constraints faced by farmers in the use of farm labour?

\section{Objectives of the Study}

The general objective of the study was to assess farm labour constraints of crop farmers in Esan west LGA, Edo state. The specific objectives of the study were to;

1. Identify the type of farm labour used by farmers for various farming activities in the study area;

2. Ascertain the constraints faced by farmers in the use of farm labour in the study area.

\section{Hypothesis of the Study}

$\mathrm{H}_{0}$ : There is no significant difference among the farm labour constraints faced by respondents in the study area.

\section{METHODOLOGY}

This study was carried out in Esan West Local Government Areas of Edo State, Nigeria. Esan West is one of the eighteen local government areas in Edo state with Ekpoma as her headquarters. It is made up of ten wards and twenty one communities. The local government covers a land mass of about $502 \mathrm{Km}$ square [12]. The population of the different communities put together according to the 2006 provisional census was figured at 125,542. The communities that constitute the local government area are Ekpoma, Iruekpen, Urohi, Ujohba, Ogwa, Ukhun, Idoa, Egoro Amede, Egoronaoka, Illeh, Emuhi, Ukpenu, Ujoelen, Uke, Ihumudumu, Ujemen, Idumebo, Uhiele, Emaudo, and Farm Settlement.

The major occupation of the people living in these communities is farming. However, there exist distribution services, petty trading and small scale enterprise like carpentry and cabinet making, welding, mechanics, hair dressing, bathing saloon and other business centers. It is predominantly an Esan speaking area. It has also accommodated other tribes such as the Igbos, Yorubas and the Hausas.

This research was carried out using survey method. Survey methods are usually used to find fact by collecting data directly from the respondents. The subject of study were respondents who engage in crop farming. The data were collected directly from the respondents with the aid of a well-structured questionnaire/interview method.

The multistage sampling technique was employed in this study. The first stage was the purposive selection of four (4) villages from the local government area. The sampled villages were Egoro Amende, Illeh, Iruekpen and Ekpoma. The second stage was the random selection of 27 farmers from each of the selected villages. This made a total of hundred (108) respondents. Data were 
analyzed using descriptive statistics involving frequency tables, percentage, mean and standard deviation. Inferential statistics comprising Friedman was used to analyze the hypothesis of the study.

\section{Measurement of Variables}

Respondents were asked to indicate the constraints faced in getting farm labour on a 4 point Likert scale ranging from very serious (4), serious (3), Little serious (2) Not serious (1). The weighted mean score was used to determine which constraints were serious or not. The weighted mean score $(2.50)$ was obtained as follows: $(4+3+2+1) / 4=2.50$. Constraints with mean values of 2.50 and above were considered as serious while others less than 2.50 were regarded as not serious.

\section{RESULTS AND DISCUSSION \\ Farm Labour Types Used by the Farmers}

Table-1: Type of farm labour used by respondents

\begin{tabular}{|l|c|c|c|c|c|c|c|}
\hline \multirow{2}{*}{ Types } & $\begin{array}{c}\text { Exchange } \\
\text { labour }\end{array}$ & $\begin{array}{c}\text { Family } \\
\text { labour }\end{array}$ & $\begin{array}{c}\text { Hired } \\
\text { labour }\end{array}$ & Exchange/Family & $\begin{array}{c}\text { Exchange } / \\
\text { Hired }\end{array}$ & $\begin{array}{c}\text { Family } / \\
\text { Hired }\end{array}$ & $\begin{array}{c}\text { Exchange/ } \\
\text { Family/ Hired }\end{array}$ \\
\cline { 2 - 9 } & $\%$ & $\%$ & $\%$ & $\%$ & $\%$ & $\%$ & $\%$ \\
\hline Clearing & 2.78 & 40.74 & 31.48 & .93 & .00 & 22.22 & 1.85 \\
\hline Weeding & .00 & 43.52 & 31.48 & 4.63 & .93 & 18.52 & .93 \\
\hline Planting & .00 & 53.70 & 24.07 & 6.48 & .00 & 14.81 & .93 \\
\hline Harvesting & .93 & 50.93 & 24.07 & 1.85 & 6.48 & 14.81 & .00 \\
\hline $\begin{array}{l}\text { Chemical } \\
\text { spraying }\end{array}$ & .00 & 37.96 & 40.74 & 2.78 & .00 & 16.67 & .93 \\
\hline Processing & 4.63 & 42.59 & 27.78 & 6.48 & .00 & 16.67 & \\
\hline Transportation & 6.48 & 39.81 & 35.19 & 1.85 & .00 & 14.81 & 1.85 \\
\hline Storage & 2.78 & 58.33 & 18.52 & 3.70 & .00 & 14.81 & 1.85 \\
\hline Fertilizers & 4.63 & 37.96 & 32.41 & 7.41 & .93 & 15.74 & .93 \\
\hline
\end{tabular}

\section{Clearing}

The response as shown in Table-1 reveals that most (40.7\%) of the respondents use family labour in clearing their farm site, followed by $31.48 \%$ and $22.22 \%$ of the respondents who used hired labour and family/Hired labour respectively.

\section{Weeding}

The result (Table-1) reveals that most $(43.52 \%)$ of the farmers in the study area used family labour in the weeding of their farm sites, followed by $31.48 \%$ of the respondents who used hired labour, and the combination of family/hired labour (18.52\%) in weeding their farms.

\section{Planting}

Most $(53.7 \%)$ of the respondents used family labour in planting their crops. The use of family labour supplements the cost hiring labour. About 24.07\%, 14.81\%, 6.48\% used hired labour, family/Hired labour and exchange/family labour respectively in the arable crop farm operation.

\section{Harvesting}

Results shows that most $(50.93 \%)$ of respondents used family labour to harvest their farm produce, followed by $24.07 \%$ of respondents that used only hired labour, $14.81 \%, 6.48 \%$ and $1.85 \%$ of the respondents used family/hired labour, exchange/hired labour and exchange/family labour respectively.

\section{Chemical Spraying}

The result revealed that $40.74 \%$ of the farmers in the study area used hired labour in spraying chemicals in their farms, followed by $37.96 \%, 16.67 \%, 2.78 \%$ of the respondents who used family labour, family/hired labour and exchange/family labour respectively.

\section{Processing}

The result revealed that most $(42.59 \%)$ of the respondents carried out the processing of their farm produce using family labour while $27.78 \%, 16.6 \%$ and $4.63 \%$ of the respondents processed their farm produce using family/hired labour and exchange labour respectively. 


\section{Transportation}

The table reveals that most (39.81\%) of the farmers used family labour to transport their produce followed by $35.19 \%$ of the respondents that used hired labour, while $14.81 \%, 6.48 \%$ and $1.85 \%$ used family/hired labour, exchange labour and exchange/family respectively.

\section{Storage}

The result of the table shows that most (58.33\%) of the farmers stored their farm produce using family labour, followed by $18.5 \%$ that made use of hired labour, while $14.81 \%, 3.70 \%, 2.78 \%$ and $1.85 \%$ made use of family/hired labour, exchange/family labour, exchange labour and exchange/family/hired labour respectively in the storing of their farm produce.

\section{Fertilizers Application}

The table shows that most (37.96\%) of the arable crop farmers applied fertilizers on their farms using family labour, followed by $32.41 \%, 15.74 \% 7.41 \%$ and $4.63 \%$ of the respondents who used hired labour, exchange/family labour and exchange labour respectively to apply fertilizers on their farms. The general result indicate that family labour was the main type of labour used by the respondent in carrying out most of their farm operations.

\section{Labour Constraints faced by Farmers}

Table 2 shows that high cost of labour was a major constraint to labour use by the farmers in the study area with a mean value of 2.84. Lack of finance also posed a serious constraints to labour use by the farmers with a mean value of 2.84. Poor job performance (2.44), scarcity of labour (2.33), theft of produce by labourers (2.07), and abandonment of work (1.67) were not considered serious constraint to labour use in the study area by the respondents.

Table-2: Labour constraints faced by respondents

\begin{tabular}{|l|r|r|r|r|r|r|r|r|r|r|}
\hline \multirow{2}{*}{ Constraints } & \multicolumn{2}{|c|}{ Very serious } & \multicolumn{2}{|c|}{ Serious } & \multicolumn{2}{|c|}{ Little serious } & \multicolumn{2}{|c|}{ Not serious } & \multicolumn{2}{c|}{ Total } \\
\cline { 2 - 13 } & Freq & $\%$ & Freq & $\%$ & Freq & $\%$ & Freq & $\%$ & Mean & $\begin{array}{c}\text { Standard } \\
\text { Deviation }\end{array}$ \\
\hline High labour cost & 34 & 31.48 & 31 & 28.70 & 35 & 32.41 & 8 & 7.41 & 2.84 & .96 \\
\hline Lack of finance & 39 & 36.11 & 27 & 25.00 & 27 & 25.00 & 15 & 13.89 & 2.83 & 1.07 \\
\hline $\begin{array}{l}\text { Poor job performance } \\
\text { of labourers }\end{array}$ & 17 & 15.74 & 32 & 29.63 & 40 & 37.04 & 19 & 17.59 & 2.44 & .96 \\
\hline Scarcity of labour & 18 & 16.67 & 26 & 24.07 & 38 & 35.19 & 26 & 24.07 & 2.33 & 1.02 \\
\hline $\begin{array}{l}\text { Theft of produce by } \\
\text { labourers }\end{array}$ & 12 & 11.11 & 26 & 24.07 & 28 & 25.93 & 42 & 38.89 & 2.07 & 1.04 \\
\hline Abandonment of work & 3 & 2.78 & 17 & \multicolumn{1}{|c|}{15.74} & 29 & 26.85 & 59 & 54.63 & 1.67 & .84 \\
\hline
\end{tabular}

\section{Test of difference in labour constraints faced by respondents}

Table-3 shows the result of the hypothesis tested for the study. It shows that there are no significant differences among the labour constraints faced by the farmers. Friedman test was used to analyze while chi-square was used to test the hypothesis. The chisquare 128.31 is significant at a $1 \%$ level. i.e., there is a significant difference in the seriousness of the constraints. High labour cost (mean rank $=4.356$ ) and lack of finance (mean rank $=4.352$ ) were not significantly different. Also the result indicates that there is no significant difference in the following constraints, lack of finance (mean rank $=4.352$ ) and poor job performance of labourers (mean rank $=3.681$ ), poor job performance of labourers (mean rank $=3.681$ ) and scarcity of labour (mean rank $=3.444$ ), scarcity of labourers (mean rank $=3.444$ ) and theft of produce by labourers (mean rank $=2.968$ ). The result however shows that the most significant problem facing the respondents was high labour cost constraints, while the least significant was abandonment of work by labourers. High cost of labour was a more significant problem to poor job performance, scarcity of labourers theft of produce by labourers and abandonment of work by labourers.

Table-3: Difference in labour constraints encountered by respondents (Friedman)

\begin{tabular}{|l|c|c|}
\hline \multicolumn{1}{|c|}{ Constraints } & \multicolumn{3}{c|}{ Mean rank } \\
\hline Abandonment of work by labourers & 2.199 & $\mathrm{e}$ \\
\hline Theft of produce by labourers & 2.968 & $\mathrm{~d}$ \\
\hline Scarcity of labour & 3.444 & $\mathrm{~cd}$ \\
\hline Poor job performance of labourers & 3.681 & $\mathrm{bc}$ \\
\hline Lack of finance & 4.352 & $\mathrm{ab}$ \\
\hline High labour cost & 4.356 & $\mathrm{a}$ \\
\hline \multicolumn{3}{|c|}{$\chi^{2}=128.31 \cdot d f=5 \cdot p<0.01$} \\
\hline
\end{tabular}

${ }^{*}$ Constraints with similar superscript are not significantly different 


\section{CONCLUSION}

The study has shown that crop farmers in the study area face few constraint regarding farm labour. The major constraints faced by them were high cost of labour and lack of finance.

\section{Recommendation}

Based on the findings of the study, it is recommended that the farmers organise themselves associations to assist each other rotationally in terms of providing labour. This will help them to address the problem of inadequate capital to hire labour, high labour cost as well as labour scarcity.

\section{REFERENCES}

1. Patel-Schneider, P. F. (2005, September). A revised architecture for semantic web reasoning. In International Workshop on Principles and Practice of Semantic Web Reasoning (pp. 32-36). Springer, Berlin, Heidelberg.

2. Olayide, M. C. (2002). Technical Efficiency and productivity of maize producers Efficiency and productivity of Maize producers within and outside the Global, 2000 projects. Agricultural Economies, 19(3): 341-348.

3. Shaib, B., Aliyu, A., \& Bakshi, J. S. (1997). Nigeria National Agricultural Research Strategy PLan: 1996-2010. Federal Ministry of Agriculture and Natural Resources, Abuja.

4. Gocowski, J., \& Oduwole, S. (2003). Labour practices in the cocoa sector of southwest Nigeria with a special focus on the role of children. STCP/IITA Monograph, IITA, Ibadan, Nigeria.

5. Oluyole, K. A., Adebiyi, S., \& Adejumo, M. O. (2007). An assessment of the adoption of cocoa rehabilitation techniques among cocoa farmers in ljebu east local government area of Ogun state. Journal of Agricultural Research and Policies, 2(1): 56-60.

6. Tanko, L., Onyenweaku, C. E., \& Nwosu, A. C. (2006). Optimum crop combination under limited resource condition: A micro level study in Yauri, Kebbi State, Nigeria. The Nigerian Agricultural Journal, 37(5): 1-10.

7. Francis, D. K. A. (2011). Factors Affecting Rural Household Farm Labour Supply in Farming Communities of South Africa. Journal of Human Ecology, 34(1): 23-28.

8. Adeoti, A.I. (2002). Economics Analysis of Irrigation and Rainfed Production System in Kwara State, Nigeria. Ph.D. Thesis, Department of Agricultural Economics, University of Ibadan. 2-15.

9. Olawale, S. (2018). Problems of Agriculture in Nigeria and Solutions. https://naijaquest.com/problems-of-agriculture-in-nigeriaand-solutions/. Accessed March 11, 2018.

10. Tompkins, A. (2016). Ghostworkers and Greens: The Cooperative Campaigns of Farmworkers and Environmentalists for Pesticide Reform. Cornell University Press. 1-14

11. Moschini, G., \& Hennessy, D. A. (2001). Uncertainty, risk aversion, and risk management for agricultural producers. Handbook of Agricultural Economics. Elsevier, 1(1), 88-153.

12. National Population Census. (2006). National Population Census Figures, NPC, 2006. 